\title{
Risks of illness of nursing professors working in in post-graduation courses
}

\author{
Risks of illness of nursing professors working \\ in post-graduation courses \\ Riesgos de enfermedad de las enfermeras docentes en el \\ contexto del trabajo de enfermería postgraduado

\section{Susan Bublitz \\ Carmem Lúcia Colomé Beck ${ }^{\mathrm{b}}$ \\ Rosângela Marion da Silvab \\ Daiane Dal Paic \\ Silviamar Camponogarab}

\section{How to cite this article:}

Bublitz S, Beck CLC, Silva RM, Dal Pai

D, Camponagara S. Risks of illness of nursing professors working in post- graduation courses. Rev Gaúcha Enferm. 2021;42:e20190514. doi: https://doi. org/10.1590/1983-1447.2021.20190514 a Universidade Federal de Santa Maria (UFSM), Hospital Universitário de Santa Maria. Santa Maria Rio Grande do Sul, Brasil.

- Universidade Federal de Santa Maria (UFSM) Departamento de Enfermagem. Santa Maria, Rio Grande do Sul, Brasil.

"Universidade Federal do Rio Grande do Su (UFRGS), Escola de Enfermagem, Departamento de Enfermagem Médico-Cirúrgica. Porto Alegre, Rio Grande do Sul, Brasil.

\section{ABSTRACT}

Objective: To identify the risk of illness related to the work context of nurse professors of stricto sensu nursing post-graduation programs of public institutions.

Method: Mixed study (convergent and parallel) carried out in federal universities in Rio Grande do Sul, with nurse professors, from November 2015 to October 2016. As data collection techniques, the Work Context Assessment Scale and a semi-structured interview were used. The data were analyzed using descriptive statistics and thematic analysis.

Results: For the quantitative data, it was identified that all factors on the scale were assessed as critical for the risk of illness. The reports complement the quantitative data, and point to work overload, competitiveness, and inadequate infrastructure.

Conclusion: This study offers subsidies for the implementation of actions aimed at the health of nursing professors and helps in the understanding of the work context, which presents risks for illness.

Keywords: Occupational health. Faculty, Nursing. Education, higher. Occupational risks. Working environment. Nursing.

\section{RESUMO}

Objetivo: Identificar o risco de adoecimento relacionado ao contexto de trabalho de enfermeiros docentes vinculados a programas de pós-graduação stricto sensu em enfermagem de instituições públicas.

Método: Estudo de abordagem mista (paralelo convergente), realizado em universidades federais do Rio Grande do Sul, com enfermeiros docentes, de novembro/2015 a outubro/2016. Como técnica de coleta de dados, utilizaram-se a Escala de Avaliação do Contexto de Trabalho e entrevista semiestruturada. Os dados foram analisados segundo estatística descritiva e análise temática.

Resultados: Na etapa quantitativa, identificou-se que todos os fatores da escala foram avaliados como críticos para o risco de adoecimento. Na etapa qualitativa, os relatos complementam os dados quantitativos, e apontam a sobrecarga de trabalho, a competitividade e a infraestrutura inadequada.

Conclusão: Os dados oferecem subsídios para a implementação de ações voltadas à saúde dos enfermeiros docentes e auxilia na compreensão do contexto de trabalho.

Palavras-chave: Saúde do trabalhador. Docentes de enfermagem. Educação superior. Riscos ocupacionais. Ambiente de trabalho. Enfermagem.

\section{RESUMEN}

Objetivo: identificar el riesgo de enfermedad relacionado con el contexto laboral de los profesores de enfermería vinculados a los programas de posgrado en enfermería stricto sensu en instituciones públicas.

Método: Estudio de enfoque mixto (paralelo convergente), realizado en universidades federales de Rio Grande do Sul, con enfermeras docentes, de noviembre/2015 a octubre/2016. Como técnica de recopilación de datos, se utilizó la Escala de evaluación del contexto laboral y la entrevista semiestructurada. A los datos se analizó de acuerdo con estadísticas descriptivas y análisis temáticos.

Resultados: En la etapa cuantitativa, se identificó que todos los factores en la escala fueron evaluados como críticos para el riesgo de enfermedad. En la etapa cualitativa, los informes complementan los datos cuantitativos y apuntan a la sobrecarga de trabajo, la competitividad y la infraestructura inadecuada.

Conclusión: Este estudio ofrece subsidios para la implementación de acciones dirigidas a la salud de los docentes de enfermería y ayuda a comprender el contexto laboral, que presenta riesgos de enfermedad.

Palabras clave: Salud laboral. Docentes de enfermería. Educación superior. Riesgos laborales. Ambiente de trabajo. Enfermería. 


\section{INTRODUCTION}

In the field of health, institutions and professionals have experienced changes in the work process in recent years, related to the relationship with users/citizens and the demands for quality and productivity, which have an impact on the work context and on the health of workers. In this scenario, educational institutions have their main actor in the professor, one of those responsible for training future professionals for the labor market ${ }^{(1)}$, especially those in the field of nursing.

Teaching has been subjected to constant challenges related to qualifications and adaptations in order to keep up with changes arising from technological advances, social changes and the demands of the labor market ${ }^{(2)}$ This category of professionals has been identified as one of the most exposed to conflicting and highly demanding environments at work. This area is evaluated according to their production, whose products are teaching activities, guidelines, scientific publications, project development, reports, patents and researches ${ }^{(3-4)}$

The management model adopted by universities has demanded more dedication, fidelity and commitment ${ }^{(4)}$, and this reality has often been achieved through the participation of professors in stricto sensu post graduation programs (PPGs). The role of postgraduate nursing, in this modality, has been essential for the advancement and consolidation of the profession, as it has a direct impact on science, technology and innovation, providing greater professional visibility ${ }^{(5)}$. However, this productive configuration, which is intensified every year and, associated with control mechanisms, leads to the increase of the work load of professors. Consequently, the situation of the work becomes substandard, which can cause dissatisfaction and illnesses in the worker ${ }^{(1)}$.

Suffering and pleasure are ways to approach the psychodynamics of work, whose object of study is the relationship between the organization of work and the processes of subjectivity of the worker, such as desires and expectations in the work context ${ }^{(6)}$. Suffering at work happens when the worker is unable to perform his activities according to his ideal, but the work organization often limits spontaneous work and prescribes a specific operating mode. Pleasure, on the other hand, is achieved when there is a new meaning for the previous suffering or a change in the work context $t^{(7)}$.

It is considered that working in stricto sensu postgraduation programs (PPGs) can represent pleasure/fulfillment or suffering/illness resulting from the work context, with repercussions on the worker's health. Based on this, the following research question was chosen: Is there a risk of illness related to the work context of nurse professors participating in stricto sensu nursing postgraduation programs in public institutions in Rio Grande do Sul? The objective of the study was to identify the risk of illness related to the work context of nurse professors related to stricto sensu nursing postgraduation programs in public institutions.

\section{METHOD}

This is a cross-sectional study, with a mixed approach, of the convergent parallel type. The convergent parallel type strategy occurs when both quantitative and qualitative elements are implemented simultaneously, during the same stage of the research process, prioritizing the methods and maintaining the independent elements during the analysis and, later, integrating the results during the interpretation ${ }^{(8)}$.

The study was developed with nurse professors working in stricto sensu postgraduation programs at three federal universities in Rio Grande do Sul, Brazil, characterized as academic master's and doctoral programs. To participate in the study, the following inclusion criteria were established: having a degree in nursing and working in a stricto sensu postgraduation program in nursing; and having been the advisor in at least one dissertation or thesis, having had the opportunity to know and carry out all the steps inherent to the experiences in the program. Professors on leave of absence of any nature in the period established for data collection were excluded.

In Table 1, it is possible to identify the population of nurse professors by institution and the number of eligible participants in each stage of the study.

From the established criteria, three were excluded for not having graduation in nursing, eight had never finished a role as advisors, four were on leave, and one was excluded because she was the researcher responsible for the study. Therefore, the eligible population was 58 professors. Among these, there were four refusals and four people did not return the research instruments. Thus, in the quantitative stage, 50 professors participated in the research and, in the qualitative stage, 20 professors.

The data collection was carried out from November 2015 to October 2016. For the quantitative stage, the professors answered the Work Context Assessment Scale (EACT), which comprises the Inventory on Work and IIIness Risks (ITRA) ${ }^{(6)}$, which is formed by four scales and aims to investigate work and the risks of illness caused by it. EACT assesses the risk of illness through the work context characterized by representations related to the organization, working conditions and social-professional relationships ${ }^{(6)}$. 
Table 1 - Distribution of professors participating in the different stages of the study. Rio Grande do Sul, 2017

\begin{tabular}{ccccc} 
Institution & Total professors & Eligible professors & $\begin{array}{c}\text { Participants in the } \\
\text { quantitative phase }\end{array}$ & $\begin{array}{c}\text { Participants in the } \\
\text { qualitative phase }\end{array}$ \\
A & 16 & 14 & 14 & 6 \\
B & 40 & 32 & 25 & 7 \\
C & 18 & 12 & 11 & 7 \\
\hline TOTAL & 74 & 58 & 50 & 20 \\
\hline
\end{tabular}

Source: 2015/2016 data survey.

This scale is self-administered and is a Likert-type psychometric scale composed of 31 items and three factors: work organization (11 items), working conditions (10 items) and social-professional relationships (10 items). Each item has five points, where: $1=$ never, $2=$ rarely, $3=$ sometimes, $4=$ often and $5=$ always. Data were treated using descriptive statistics like frequency, mean and standard deviation by factor, as the instrument consists of negative items. The following results can be considered for this scale: means above $3.7=$ negative assessment, which indicates that the work context offers substantial possibilities for the professionals to get ill; means between 2.3 and $3.69=$ moderate, critical assessment, which indicates that the work context moderately favors the possibility of the professionals becoming ill; and means below $2.29=$ positive, satisfactory assessment, indicate that the work context favors the health of the professional.

To assist in the quantitative data collection stage, a professor from each higher education institution (IES) appointed a student collector (undergraduate or postgraduate) and, in the institution of origin of the study, two academics were appointed, thus totaling four research assistants, who were individually guided, trained and certified in online and/or face-to-face meetings for this purpose. The data collection instrument was delivered in envelopes and a date was scheduled for collection, at which time the verification of the completion of all items was carried out.

After the completion of the quantitative phase, the qualitative stage began, through a semi-structured interview applied by the responsible researcher in order to deepen and complement the quantitative data. It should be noted that the following guiding questions were explored: How do you perceive working conditions in postgraduation (in relation to infrastructure, interpersonal relationships, colleagues, leadership, and tasks)? Do you identify effects of your work on your health (physical, psychological, and social effects)? The interviews were coded with the letter $D$ (professor) followed by a sequential cardinal number according to the order of data collection. They lasted an average of 50 minutes and were recorded with the participants' authorization.

The selection of participants for this stage was determined randomly, among the professors who participated in the quantitative stage of the study, respecting the proportionality among respondents by institution. The participants were contacted by email, and the availability to participate in this stage was verified. In view of the positive feedback, the interviews were scheduled at a time and place selected by the respondent. The number of interviews was defined according to data saturation criteria ${ }^{(9)}$.

For the analysis of the quantitative data, a database was built in a spreadsheet of Excel for Windows, in which the data were organized by means of independent double typing, carried out by the research author and one of the assistants. After correcting errors and inconsistencies, the results were analyzed using the Statistical Analysis System (SAS - version 9.02). The instrument's reliability was assessed by Cronbach's Alpha Coefficient, and the interviews were analyzed according to thematic analysis ${ }^{(10)}$.

This study was approved by the Research Ethics Committee (CEP), under Opinion no 1,219,043, in 2015 and with CAAE no 48451615.0.0000.5346. The development of the research followed the Regulatory Guidelines and Norms for Research involving Human Beings, as established by the Resolution of the National Health Council 466/2012.

\section{RESULTS}

Regarding the sociodemographic profile, there was a predominance of females $(49 ; 98 \%)$, from 51 to 60 years old $(23 ; 64 \%)$ and married $(37 ; 74 \%)$. 
Regarding the work context, Table 2 shows that all factors of EACT were assessed as critical for the risk of illness, which suggests that they contribute moderately to the illness of the participants.

Regarding work organization, it is noteworthy that, in the general distribution of the factor, 29 (58\%) participants presented a critical evaluation, while 19 (38\%) evaluated it seriously and two (4\%) satisfactorily. Chart 1 shows the work organization factor, its items, and the risk classification.

In the social-professional relations factor, 22 (64\%) had a critical assessment, while 12 (24\%) assessed satisfactorily and six (12\%), severely. Chart 2 shows the social-professional relationships factor, its items, and the risk classification.

Regarding the working conditions factor, there is a similarity between those who consider them as critical 24 (48\%) and serious 22 (44\%). A total of four (8\%) respondents rated this factor satisfactorily. Chart 3 shows the working conditions factor, its items, and risk classification.

Regarding the qualitative stage, when asked about the perception about working conditions in postgraduation education, the professors mentioned work overload, competitiveness among colleagues in the program and inadequate infrastructure as aspects that promote illness in the job.

Table 2 - Work Context Assessment (EACT). Rio Grande do Sul, 2017

\begin{tabular}{|c|c|c|c|c|c|c|}
\hline $\begin{array}{c}\text { Work Context Assessment } \\
\text { Scale (EACT) }\end{array}$ & Mean & SD & Minimum & Maximum & $\begin{array}{l}\text { Cronbach's } \\
\text { alpha }\end{array}$ & $\begin{array}{l}\text { Risk } \\
\text { rating }\end{array}$ \\
\hline Organization of work & 3.46 & 0.54 & 1.55 & 4.33 & 0.784 & Critical \\
\hline Social-professional relations & 2.79 & 0.68 & 1.40 & 4.60 & 0.886 & Critical \\
\hline Work conditions & 3.46 & 0.87 & 1.10 & 5.00 & 0.953 & Critical \\
\hline
\end{tabular}

Source: 2015/2016 data survey.

\begin{tabular}{|c|c|c|c|c|}
\hline \multirow{12}{*}{$\begin{array}{c}\text { Organization } \\
\text { of work } \\
(\mu=3.46, S D=0.54)\end{array}$} & Item & Mean & SD & CR \\
\hline & 1. The pace of work is excessive & 4.14 & 0.775 & Severe \\
\hline & 2. Tasks are accomplished with deadline pressure & 4.00 & 0.800 & Severe \\
\hline & 3. There is a strong demand for results & 4.12 & 1.013 & Severe \\
\hline & 4. The rules for performing tasks are strict & 3.46 & 1.024 & Critical \\
\hline & 5. Performance is monitored & 3.12 & 1.177 & Critical \\
\hline & 6. The number of people is insufficient to carry out the tasks & 3.78 & 0.965 & Severe \\
\hline & 7. The expected results are unrealistic & 2.84 & 1.027 & Critical \\
\hline & 8. There is a division between those who plan and who execute & 3.16 & 0.880 & Critical \\
\hline & 9. Tasks are repetitive & 2.88 & 0.816 & Critical \\
\hline & 10. There is no time to take breaks from work & 3.44 & 0.941 & Critical \\
\hline & 11. The tasks performed are discontinued & 3.18 & 0.973 & Critical \\
\hline
\end{tabular}

Chart 1 - Mean, standard deviation (SD) and risk classification (CR), by item of the EACT work organization factor. Rio Grande do Sul, 2017

Source: Research data, 2017 


\begin{tabular}{|c|c|c|c|c|}
\hline \multirow{11}{*}{$\begin{array}{c}\text { Social-professional } \\
\text { relations } \\
(\mu=2.79, S D=0.68)\end{array}$} & Item & Mean & SD & CR \\
\hline & 12. Tasks are not clearly defined & 2.54 & 0.984 & Critical \\
\hline & 13. Autonomy does not exist & 2.26 & 0.890 & Satisfactory \\
\hline & 14. The distribution of tasks is unfair & 2.70 & 0.964 & Critical \\
\hline & 15. Employees are excluded from decisions & 2.62 & 1.037 & Critical \\
\hline & $\begin{array}{l}\text { 16. There are difficulties in communication between } \\
\text { managers and subordinates }\end{array}$ & 2.38 & 0.998 & Critical \\
\hline & 17. There are professional disputes in the workplace & 3.88 & 0.840 & Severe \\
\hline & 18. Lack of integration in the work environment & 3.64 & 0.794 & Critical \\
\hline & $\begin{array}{l}\text { 19. Communication between employees } \\
\text { is unsatisfactory }\end{array}$ & 3.02 & 0.948 & Critical \\
\hline & $\begin{array}{l}\text { 20. There is a lack of management support for my } \\
\text { professional development }\end{array}$ & 2.32 & 1.240 & Critical \\
\hline & $\begin{array}{l}\text { 21. The information I need to perform my tasks is } \\
\text { difficult to access }\end{array}$ & 2.60 & 0.938 & Critical \\
\hline
\end{tabular}

Chart 2 - Mean, standard deviation (SD) and risk classification (CR) by item of the EACT Social-Professional Relations factor. Rio Grande do Sul, 2017

Source: Research data, 2017.

\begin{tabular}{|c|c|c|c|c|}
\hline \multirow{11}{*}{$\begin{array}{c}\text { Work } \\
\text { conditions } \\
(\mu=3.46, S D=0.87)\end{array}$} & Item & Mean & SD & CR \\
\hline & 22. Working conditions are precarious & 3.66 & 0.972 & Critical \\
\hline & 23. The physical environment is uncomfortable & 3.70 & 0.985 & Severe \\
\hline & 24. There is a lot of noise in the work environment & 3.64 & 1.109 & Critical \\
\hline & 25. The furniture in the workplace is inadequate & 3.62 & 1.164 & Critical \\
\hline & 26. Work tools are insufficient to carry out the tasks & 3.46 & 0.943 & Critical \\
\hline & 27. The job position is inadequate to carry out the tasks & 3.42 & 1.115 & Critical \\
\hline & 28. The equipment needed to perform the tasks is precarious & 3.48 & 1.024 & Critical \\
\hline & 29. The physical space to perform the work is inadequate & 3.78 & 1.006 & Severe \\
\hline & 30. Working conditions pose risks to the safety of people & 2.60 & 1.000 & Critical \\
\hline & 31. Consumables are insufficient & 3.32 & 1.009 & Critical \\
\hline
\end{tabular}

Chart 3 - Mean, standard deviation (SD) and risk classification (CR), by item of the EACT Working Conditions factor. Rio Grande do Sul, 2017

Source: Research data, 2017. 


\section{Work overload}

Professors have to reconcile activities with undergraduation and postgraduation students, which is often identified as a factor that generates work overload.

Our workload as a group of professors today is very large, so I think it affects us more than the job itself in postgraduation education. Because, if I had less of a burden in graduation and here in postgraduation too, less students (...), I think it would be much better to work. It is not bad when you can "marry" everything, but the point is that today we are few, to do many things. We have been few for a long time. (D7).

I think that sometimes we ask for more than we can handle. So, we end up getting sick. You are not just a researcher. You also need to go to classes, in the day-today, then there are extension activities, there is a family, there are friends, you know... you get into a crisis (...) (D6). We can't handle everything, at least I try, but I can't. I think whoever does this ends up getting sick. (D7).

According to the testimonies, professors felt they were overwhelmed with the work demands.

\section{Competitiveness}

Postgraduation programs have enhanced research productivity, which put pressure on professors to have more publications and, consequently, has increased individualization and the competitive environment in this environment.

(...) I have been seeing, that there is a certain competitiveness. So, this sometimes disturbs people's relationships alittle. (D11).

Regarding colleagues (...) I think the trend is to increase the dispute. l even think that when thinking about postgraduation education, with these separation of those who produce qualis capes level A, who produces at level $B$, this favors an internal dispute logic (...) (D20).

\section{Inadequate infrastructure}

In addition to the work overload and competition among colleagues, the participants highlighted that the infrastructure does not provide a favorable environment for concentration in the activities required by postgraduation activities.
The main problem that I also see in our program is the lack of physical structure (...) (D2).

Because when advising students, writing articles, you have to be in an environment (...) whereyou can focus on that alone. We don't have a place just for us (...) we have a room with nine professors, but it is not at the program, it is a room in the course department (...) and academic production requires concentration. So, on this issue of structure, I think we have to improve. (D1).

The lack of adequate materials and equipment to carry out their tasks was highlighted by the professors as a point that should be improved.

(...) we don't always have the equipment we want. Sometimes, we want to innovate, do something different and there is no Internet, the auditorium you need ... this causes stress, discomfort, because we have a limitation, we cannot resolve it, it does not depend on us. It depends on us saying that things are not good and not accepting it (...) (D4).

\section{DISCUSSION}

The analysis of the results shows that the three factors that make up the EACT were critically evaluated, which suggests that these contribute moderately to the illness of the nurse professors of the postgraduation programs. When evaluating the items individually and when analyzing the professors' reports, situations that were seriously assessed for the risk of illness were identified, such as: work overload, professional disputes in the workplace and inadequate infrastructure.

The organization of work is determined as the division of labor and the content of tasks, rules, controls and work rhythms ${ }^{(6)}$ and these elements are dynamically interrelated and mediate the subjectivity processes of the worker, which may directly imply their health. In this factor, four items received a severe assessment for the risk of illness. The item with the worst evaluation was "the pace of work is excessive" $(\mu=$ 4.14), accompanied by "there is a strong demand for results" ( $\mu=4.12)$, "the tasks are accomplished with deadline pressure" ( $\mu=4.00)$ and "the number of people is insufficient to carry out the tasks" ( $\mu=3.78)$. It is worth mentioning that no item of this factor was evaluated by professors as satisfactory, that is, as a situation that promotes health of workers.

The work overload and the fast pace of work were also mentioned in the interviews as situations that affect the health of professors, and the data from the two stages of 
data collection converged. The results found are similar to a study carried out with higher education professors from a public institution located in the Amazon region ${ }^{(11)}$, which found dissatisfaction with the organization of work in view of the pressure to meet deadlines, increasing the time that the professor spends at work, the pressure for achieving results, and increases in teaching work. International studies have identified that the overload of tasks causes the professor to prolong his workday at home, thus impairing moments of leisure and family relationships ${ }^{(12-14)}$.

It was found that the accumulation of activities that professors experience is strongly linked to the changes that have occurred in the world of work, requiring them to perform tasks that transcend the work period. Nowadays, the performance of the professor of higher education is not restricted to graduation activities, incorporating, for the most part, activities in postgraduation studies and research. Such experiences allow the professor to have a greater diversity of activities; however, this can lead to overload ${ }^{(15)}$.

Research activities were related to work overload and demands for results, which reflected in the professors'feelings of concern and anguish to achieve the institutional goals of scientific production and publication ${ }^{(2)}$. This context, strongly influenced by results, favors a climate of dispute and competition among nursing professors in postgraduation programs.

In this context, it has been highlighted that, in the social-professional relations factor, an item was assessed as severe for the risk of illness: "there are professional disputes in the workplace". When analyzing the interviews, competitiveness was cited by professors as a situation that negatively interferes with healthy relationships between peers. This data corroborates an integrative review, which sought to highlight the factors that generate pleasure and suffering in nursing teaching and identified interpersonal relationships as the factor that leads to the greatest suffering among professors ${ }^{(16)}$.

The current management models adopted by the PPGs, the evaluation of professors by development agencies and those linked to postgraduate studies, adopt, in essence, the pressure for growth in production and publication and create a dispute and rivalry between peers. In addition, the intention to maintain scholarships or obtain funds in order to equip laboratories and study rooms and travel expenses for congresses also arouses intense competition among professors from the same PPG ${ }^{(17)}$.

In this context, it is clear that the disharmony in the postgraduate environment has intensified among professors. These professionals, previously colleagues and solidary partners, today become adversaries and competitors categorized into classes, which differ according to the volume of publications and the classification of the journals that accept and publish their scientific papers ${ }^{(1)}$. As an effect of this competitiveness, there is, on the one hand, the weakening of solidarity among professors, and on the other, the appearance of numerous institutional symptoms, such as stress, work accidents, absenteeism, illness, presenteeism, drops in productivity, complaints about low quality products and services ${ }^{(3)}$.

Regarding the working conditions factor, which concerns the quality of the physical environment, the workplace, the equipment and materials made available for carrying out work activities ${ }^{(6)}$, two items were identified as having a severe assessment for the risk of illness: "The physical space to perform the work is inadequate" and "the physical environment is uncomfortable". The other items received a moderate evaluation, and none received a satisfactory evaluation, that is, was found favorable for the health of the professors.

Inadequate infrastructure was also addressed by professors in the qualitative stage of the study. In this context, what has been observed is that the accelerated expansion of Brazilian higher education has not been accompanied, at the same pace, by expansions in infrastructure, equipment, and the number of human resources ${ }^{(4)}$.

This structural problem means professors have to improvise constantly in an attempt to make up for the lack of resources. The lack of materials, equipment, and of a location that favors concentration is directly related to the quality of the teaching work, as well as to the health of these workers, since they are frustrated by the precarious working conditions offered ${ }^{(4)}$.

It is possible to identify that the nurse professor is a professional committed to the construction of knowledge, who has the intention of training human resources that will propagate the practice of care. However, these professionals sometimes find themselves immersed in a work context with several requirements and responsibilities and, on several occasions, do not have the ideal conditions for the development of their activities $^{(18)}$. Thus, it is worth noting that the health conditions of workers is closely related to the demands of the job and the conditions for its performance, arising from the context and characteristics of the work organization ${ }^{(19-20)}$.

In this study, from the perspective of psychodynamics at work, it can be inferred that the nursing professors of PPGs have expectations regarding the development of their activities, which are sometimes prejudiced by the work context that is presented to them. It was possible to verify 
that work overload, competitiveness among colleagues and inadequate infrastructure are risk factors for the health of nursing professors and, if not reframed or restructured, may result in illness for these workers.

\section{$\square$ CONCLUSIONS}

In this study, it was possible to assess the risk of illness related to the work context of nurse professors in the stricto sensu postgraduation programs in nursing at three public institutions in Rio Grande do Sul. Professors assessed their work context as varying from moderate (critical) to high (severe) with regard to the risk of illness. In the factors "work organization" and "working conditions", there were no items with a positive evaluation that favored the health of the professors.

The mixed research approach made it possible to aggregate qualitative elements that allowed us to observe work overload, competitiveness and inadequate infrastructure as working conditions that seriously affect professors' health. In this sense, situations that produce suffering at work are constituted, requiring immediate measures to seek greater satisfaction in this work activity.

Thus, in order to avoid illness and promote health, there is a need to reflect on situations in the work context that can be changed. As suggestions, the following are recommended: increase the number of professors in order to avoid work overload, provide integration dynamics among colleagues in the same program in order to reduce the competition in this environment and provide better working conditions, with investment in infrastructure - adequate rooms, furniture that favors good accommodation and appropriate equipment for the development of activities. It is noteworthy that such changes may have positive repercussions not only for these professionals, but also for the quality of the teaching provided and, consequently, in the training of masters and doctors in nursing.

Finally, as limitations, this research happened in only one Brazilian state, thus, needing to be extended to other regions of the country. In addition, the research was only applied at federal universities. The inclusion of private universities in future researches could be considered as a way to complement and compare the data found.

As contributions to the area of health and nursing, this study, in general, highlights important aspects related to the health of nursing professors of PPGs, offering subsidies for the implementation of actions aimed at the health of these workers. In addition, the study also offers subsidies for the Brazilian postgraduation system, as it helps to understand the work context of these professionals.

\section{REFERENCES}

1. Penteado RZ, Souza NS. Teacher malaise, suffering and sickness: from narratives of teacher work and culture to teaching as a profession. Saude Soc. 2019;28(1):135-13. doi: https://doi.org/10.1590/s0104-12902019180304

2. Araújo PC, Maduro M, Zogahib A, Lima 0, Silva LC. Avaliação sobre Qualidade de Vida no Trabalho entre os docentes de duas Instituições de Ensino Superior: uma realidade no Estado do Amazonas. Rev Eletrôn Gestão Soc. 2016;9(23):961976. doi: https://doi.org/10.21171/ges.v9i23.1931

3. Pizzio A, Klein K. Qualidade de vida no trabalho e adoecimento no cotidiano de docentes do ensino superior. Educ Soc. 2015;36(131):493-513. doi: https://doi. org/10.1590/ES0101-73302015124201

4. D'Oliveira CAFB, Almeida CM, Souza NVDO, Pires A, Madriaga LCV, Mó TC, et al. Teaching work of nursing and the impact on the health-disease process. Rev Fund Care Online. 2018 [cited 2019 Sept 07];10(1):196-202. Available from: https://doi.org/10.9789/2175-5361.2018.v10i1.196-202

5. Scochi CGS, Munari DB, Gelbcke FL, Ferreira MA. The challenges and strategies from graduate programs innursing for the dissemination of scientific production at international journals. Esc Anna Nery. 2014 [cited 2019 Sep 07];18(1):510. Available from: http://www.scielo.br/pdf/ean/v18n1/en_1414-8145ean-18-01-0005.pdf

6. Mendes AM, Ferreira MC. Inventário sobre o trabalho e riscos de adoecimento ITRA: instrumento auxiliar de diagnóstico de indicadores críticos no trabalho. In: Mendes A, organizador. Psicodinâmica do trabalho: teoria, método e pesquisas. São Paulo (SP): Casa do Psicólogo; 2007. p. 111-26.

7. Dejours C. A carga psíquica do trabalho. In: Dejours C, Abdoucheli E, Jayet C, Betiol MIS. Psicodinâmica do trabalho, contribuições da Escola Dejouriana à análise da relação prazer, sofrimento e trabalho. São Paulo: Atlas; 2011. p. 21-32.

8. Creswell JW, Clark VLP. Pesquisa de métodos mistos. 2. ed. Porto Alegre: Penso; 2013.

9. Minayo MCS. [Sampling and saturation in qualitative research: consensuses and controversies]. Rev Pesq Qualit. 2017 [cited 2019 Sep 07];5(7):112. Portuguese. Available from: https://editora.sepq.org.br/rpq/article/ view/82/59

10. Bardin L. Análise de conteúdo. 4. ed. Lisboa: Edições 70; 2011.

11. Tundis AGO, Janine Kieling Monteiro JK. Ensino superior e adoecimento docente: um estudo em uma universidade pública. Psicol Educ. 2018 [cited 2020 Apr 19];46:1-10. Available from: https://ken.pucsp.br/psicoeduca/article/ viewFile/39139/26512

12. Muto S, Muto T, Seo A, Yoshida T, Taoda K, Watanabe M. Job stressors and job stress among teachers engaged in nursing activity. Industrial Health. 2007;45(1):44-8. doi: https://doi.org/10.2486/indhealth.45.44

13. Yildirim D, Yildirim A, Timucin A. Mobbing behaviors encountered by nurse teaching staff. Nurs Ethics. 2007;14(4):447-63. doi: https://doi. org/10.1177/0969733007077879

14. Whalen KS. Work-related stressors experienced by part-time clinical affiliate nursing faculty in baccalaureate education. Int J Nurs Educ Scholarsh. 2009;6:Article30. doi: https://doi.org/10.2202/1548-923X.1813

15. Soares SR, Cunha MI. Qualidade do ensino de graduação: concepções de docentes pesquisadores. Avaliação. 2017;22(2):316-31. doi: https://doi. org/10.1590/s1414-40772017000200003 
16. Fernandes MNS, Lopes LFD, Coronel DA, Weiller TH, Viero V, Freitas PH. Prazer e sofrimento no trabalho de docentes de enfermagem: revisão integrativa. Rev Aten Saúde. 2017;15(53):95-102. doi: https://doi.org/10.13037/ras.vol15n53.4610

17. Pioli E, Silva EP, Heloani JRM. Plano Nacional de Educação, autonomia controlada e adoecimento do professor. Cadernos Cedes. 2015;35(97):589-607. doi: https://doi.org/10.1590/CC0101-32622015154849

18. Duarte CG, LunardiVL, Barlem ELD. Satisfaction and suffering in the work of the nursing teacher: an integrative review. REME - Rev Min Enferm. 2016;20:e939. doi: https://doi.org/10.5935/1415-2762.20160009
19. Macêdo KB, Lima JG, Fleury ARD, Carneiro CMS, organizadores. Organização do trabalho e adoecimento - uma visão interdisciplinar. Goiânia: Ed. da PUC Goiás; 2016 [cited 2019 Sep 07]. Available from: https://www.medicina.ufmg.br/ osat/wp-content/uploads/sites/72/2017/06/Livro-organização-do-trabalhoe-adoecimento-mpt21-06-2017.pdf

20. Droogenbroeck FV, Spruyt B. Do teachers have worse mental health? review of the existing comparative research and results from the Belgian Health Interview Survey. Teaching Teacher Educ, 2015;51:88-100. doi: https://doi.org/10.1016/j. tate.2015.06.006

\section{- Corresponding author:}

Susan Bublitz

Email: susan.bublitz@gmail.com

\section{Associate editor:}

Wiliam Wegner 